\title{
Tridimensional matrices of mussels Perumytilus purpuratus on intertidal platforms with varying wave forces in central Chile
}

\author{
Jorge L. Alvarado, Juan C. Castilla* \\ Estación Costera de Investigaciones Marinas, Facultad de Ciencias Biológicas, P. Universidad Católica de Chile, \\ Casilla 114-D, Santiago, Chile
}

\begin{abstract}
Perumytilus purpuratus is the dominant competitor for primary substrate in the mid-intertidal zone of central Chile's rocky shores. This mussel is capable of forming dense matrices (beds) that support rich infaunal and epiphytic communities. Three platforms, exposed, semi-exposed, and sheltered, were sampled to determine aspects of the mussel $P$. purpuratus size structure and temporal dynamics. Palumbi's dynamometers were used to measure intertidal wave forces. Mussel samples from the 3 platforms were collected approximately every second month between April 1982 and June 1983. For sampling, mussels were removed sequentially in order to maintain the stratified structure (layers) of the mussel matrices. Populations of $P$. purpuratus show a bimodal size distribution when considering their entire size range. Although this bimodality is consistent through time and space, our results show important differences for the size distributions both spatially and temporally. Spatially, the differences could arise as a result of varying wave exposures. Adults showed a higher mean size with decreasing exposure. Temporally, the differences arise due to changes in the number of recruits entering the population. Within platforms, the observed differences when comparing upper and lower mussel layers could arise as a result of differential survival and growth rates between them. We also suggest that retention of recruits is higher in lower layers due to increased complexity of the matrix and reduced water flow. The sampling method developed to collect separate mussel layers proved to be crucial for the recognition of population dynamics processes occurring within the stratified structure of mussel matrices.
\end{abstract}

KEY WORDS: Mussels - Perumytilus purpuratus - Wave exposure - Bimodality - Size distribution

\section{INTRODUCTION}

Perumytilus purpuratus (Lamarck, 1819) is one of the most common rocky intertidal mussels along the southeastern Pacific coast of South America, from Ecuador to the Strait of Magellan, extending also to the Atlantic coast of South America, as far as Santa Cruz, Argentina (Osorio \& Bahamonde 1968). P. purpuratus forms intertidal 'beds': tridimensional matrices of organisms in the mid-intertidal fringe (Lozada 1964 , Castilla 1981). These mussel beds have been considered as monospecific matrices (Castilla 1981, Paine et

\footnotetext{
- Addressee for correspondence.

E-mail: jcastill@genes.bio.puc.cl
}

al. 1985), with P. purpuratus being the species that uses the primary substrate (rock), out-competing other sessile organisms such as barnacles, algae, and other mussel species (Castilla \& Durán 1985, Paine et al. 1985, Suchanek 1986, Castilla et al. 1989, Durán \& Castilla 1989, Navarrete \& Castilla 1990). Mussel beds have also been considered as microhabitats enhancing the establishment of assemblages of different sessile and mobile organisms (Tokeshi et al. 1989), or acting as communities in themselves (Reish 1964, Penchaszadeh 1973, Suchanek 1979). They also show a high structural heterogeneity (Suchanek. 1979, 1986)

Size distributions of Perumytilus purpuratus have been documented in the literature (Lozada 1964, Paine et al. 1985), however, the emphasis has been placed on 
mussels above $2 \mathrm{~mm}$, making the identification and counting processes easier Paine et al. (1985) reported a relatively uniform size distribution for $P$. purpuratus based on samples of 3 Chilean coastal localities.

Preliminary observations suggested to us the occurrence of bimodality in bed samples of Perumytilus purpuratus. Bimodal size distributions have recently been reported for populations of a wide range of organisms, including animals and terrestrial plants (Pollock 1979, Griffiths \& Seiderer 1980, Tegner \& Levin 1983, Huston 1986). Huston \& DeAngelis (1987) reviewed the potential mechanisms causing bimodality in monospecific populations. The mechanisms described include inherent ones such as sexual dimorphism, genetic variation, and maximum size limits. Also reported were imposed mechanisms such as competition, predation, and environmental heterogeneity. Recently, Botsford et al. (1994) reformulated the interpretation of the main ('somewhat counterintuitive') mechanisms causing bimodality based on a size-structured demographic model.

Wave impact has been recognized as an important factor influencing the spatial and temporal distribution of organisms in the intertidal zone Jones \& Demetropoulos 1968, Harger 1970, Koehl 1982, Palumbi 1984, Denny 1988). Most of this work has been focused on morphological adaptations and the biomechanics of the organisms attached to substrate in exposed environments (Koehl 1984, 1986, Vogel 1984, Denny 1987). The effects of wave exposure on the population structure and dynamics of intertidal species has also been documented, but to a lesser extent (Harger 1970. Harger \& Landenberger 1971, Leigh et al. 1987).

In this paper we analyze the size frequency distributions of Perumytilus purpuratus beds in samples from 3 sites, each experiencing a different wave exposure. We discuss processes capable of producing the observed bimodal patterns found in $P$. purpuratus mussel beds.

\section{MATERIALS AND METHODS}

The study was conducted on the rocky shore of the Estación Costera de Investigaciones Marinas, P. Universidad Católica de Chile at Las Cruces, Chile: $33^{\circ} 29^{\prime} \mathrm{S}, 71^{\circ} 38^{\prime} \mathrm{W}$ (Castilla \& Durán 1985). The working sites were 3 metamorphic gneiss platforms (Oliva \& Castilla 1986) in which there were dense Perumytilus purpuratus beds. Initially, the platforms were subjectively classified as exposed, semi-exposed and sheltered.

One mussel sample per platform was taken from April 1982 to June 1983, approximately every second month. A $20 \times 20 \mathrm{~cm}$ steel quadrat was inserted in the matrix and mussels were removed from inside the quadrat until the bottom was free of macroscopic indi- viduals. This removal process was done sequentially, identifying different layers by painting the mussels visible to the remover inside the quadrat. Layers were identified as upper, middle and lower, and the mussels collected from each layer kept separate.

All mussels collected from each site were measured by recording the total length. For the larger mussels, measurements were taken using a vernier caliper to the nearest $0.1 \mathrm{~cm}$; for the smaller ones, those usually attached to the byssal threads of larger conspecifics, measurements were taken using a microscope graticule to the nearest $0.001 \mathrm{~mm}$.

Size distributions were compared using maximum likelihood analysis of variance (ANOVA; Proc CATMOD; SAS Institute Inc. 1988) which uses maximum likelihood estimation to find the parameter values and generalized Wald statistics for the hypothesis testing. The number of size classes was reduced both to avoid frequencies of zero within the range, and to increase effective sample size per class. Thus, we used 10 mussel size classes of $4 \mathrm{~mm}$ each. Paired tests were used to compare the distributions of interest (platforms, months or layers) following the same method. The November 1982 sample for the exposed platform was lost. Hence, this month was excluded from the statistical analyses. In the case of the layers, we compared only upper and lower layers, due to the absence of the middle layer in some of the samples. Adult size-distributions were compared using Studentized Maximum Modulus' (SMM) multiple comparison procedure (Proc GLM; SAS Institute Inc. 1988) for differences in mean size, and Proc CATMOD for comparison of frequencies. In this case, we excluded juveniles, mussels smaller than $10 \mathrm{~mm}$ in length (Lozada \& Reyes 1981), from the analysis.

Several years after taking and analyzing the samples, observations were made at the same mussel bed platforms to assess the wave forces acting upon them. The intertidal wave force measuring device developed by Palumbi (1984) was used. In the first observation (April 1988) wave forces were determined using 4 of Palumbi's dynamometers mounted on a wooden plate: $10 \mathrm{~cm}$ wide, $40 \mathrm{~cm}$ long and $1 \mathrm{~cm}$ thick. The dynamometers were $10 \mathrm{~cm}$ apart on each plate, and fixed on each platform using anchoring bolts. Maximum wave forces were registered from low to high tide at $1 \mathrm{~h}$ intervais. Nevertheless, only mean-maximum wave force values were compared using ANOVAs followed by SMM multiple comparison procedure (Proc GLM; SAS Institute Inc. 1988). In the second observation (September 1994), wave forces were determined using the same dynamometers placed on aluminum plates: $10 \mathrm{~cm}$ wide, $65 \mathrm{~cm}$ long and $0.2 \mathrm{~cm}$ thick. The dynamometers were $15 \mathrm{~cm}$ apart. On this occasion, observations were carried out continually for $5 \mathrm{~d}$. Due to 
Table 1. Wave exposure. Values are mean $\pm \mathrm{SE}$ maximum wave forces $\left(\mathrm{N} \mathrm{m}^{-2}\right)$ registered at 3 rocky platforms on which there were dense Perumytilus purpuratus beds. SMM multiple comparisons were performed among platforms by days. Means with the same letter are not significantly different $(\alpha=0.01)$

\begin{tabular}{|c|c|c|c|c|c|c|}
\hline \multirow[t]{2}{*}{ Date } & \multirow[t]{2}{*}{ Exposed } & \multirow[t]{2}{*}{ Semi-exposed } & \multirow[t]{2}{*}{ Sheltered } & \multicolumn{3}{|c|}{ SMM multiple comparison among platforms } \\
\hline & & & & Exposed & Semi-exposed & Sheltered \\
\hline 6 Apr 1988 & $11882 \pm 308$ & $8330 \pm 283$ & $7840 \pm 566$ & $\mathrm{a}$ & $\mathrm{b}$ & $b$ \\
\hline 5 Sep 1994 & - & $12139 \pm 1066$ & $7016 \pm 736$ & - & $\mathrm{a}$ & $\mathrm{b}$ \\
\hline 6 Sep 1994 & $20194 \pm 594$ & $11359 \pm 988$ & $6905 \pm 643$ & a & $\mathrm{b}$ & $\mathrm{c}$ \\
\hline 7 Sep 1994 & $25242 \pm 2970$ & $10691+1013$ & $7016 \pm 1170$ & a & $\mathrm{b}$ & $\mathrm{b}$ \\
\hline 8 Sep 1994 & $15925 \pm 898$ & $9800 \pm 481$ & $5568 \pm 782$ & a & $\mathrm{b}$ & $\mathrm{C}$ \\
\hline $9 \operatorname{Sep} 1994$ & $7907 \pm 334$ & $1225 \pm 640$ & 0 & $\mathrm{a}$ & $\mathrm{b}$ & $b$ \\
\hline
\end{tabular}

observed sea conditions (storm), no measurements were obtained for the exposed site during the first day. Maximum wave forces were compared using ANOVAs and the SMM multiple comparison procedure.

\section{RESULTS}

Statistical analyses on maximum wave forces showed significant differences for the majority of comparisons among platforms (Table 1, Fig. 1). The highest mean values were always recorded on the exposed platform, whilst the lowest values were always recorded on the sheltered one (Table 1 ).

The observed mussel size distribution, when pooling all samples, corresponds to a multimodal distribution with 2 main peaks (Fig. 2).

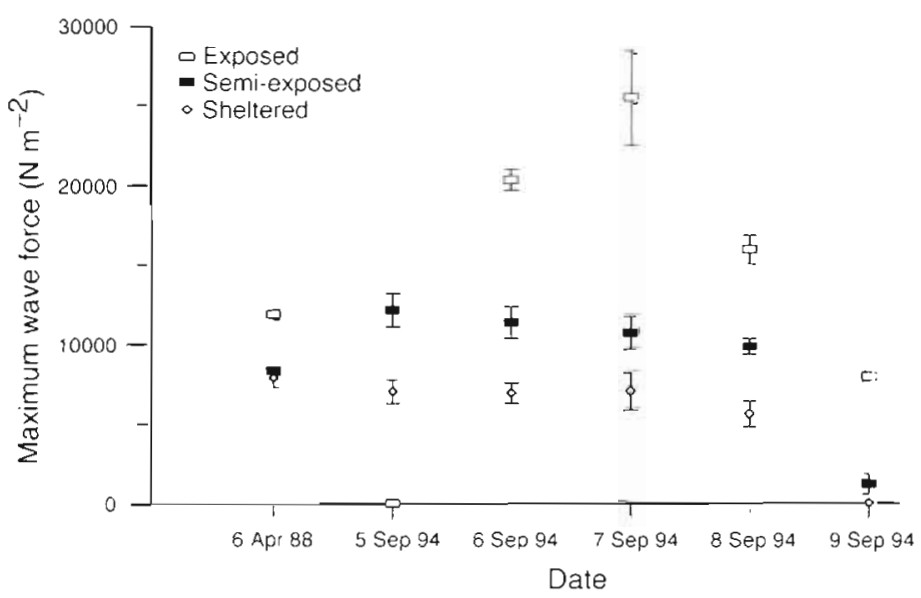

Fig. 1. Mean-maximum wave forces $\left(\mathrm{N} \mathrm{m}^{-2}\right)$ recorded on 3 mussel platforms during observations conducted at Las Cruces rocky intertidal (Chile). Values are mean $\pm \mathrm{SE}$

The first peak is located in the 0 to $2 \mathrm{~mm}$ range, and corresponds to recently settled individuals (Ramorino \& Campos 1979, 1983). The second peak is located in the 26 to $28 \mathrm{~mm}$ range, and corresponds to the adult segment of the population.

Among platforms (Fig. 3), the statistical analyses showed significant differences for both the size distributions (Proc CATMOD; $\chi^{2}=603.9,16 \mathrm{df}, \mathrm{p}<0.0001$ ) and the mean size of adults ( $>10 \mathrm{~mm}$ ) ( $F=128.6,2 \mathrm{df}$, $p<0.0001)$. Paired chi-squared tests indicate that all platforms were significantly different $(p<0.0001)$ for both the total and adult distributions. The SMM paired tests showed that, in the case of adult size distributions, all the comparisons among platforms were significantly different $(m=2.39,3121 \mathrm{df}, \mathrm{p}<0.01)$. The highest mean adult size was found on the sheltered platform $(25.87 \mathrm{~mm})$; an intermediate mean size on the semi-exposed platform $(25.15 \mathrm{~mm})$, and the lowest mean size value on the exposed one $(22.07 \mathrm{~mm})$.

Among dates (Fig. 4), the most important differences in the size distributions are related to the number of recruits, even though bimodality is always present.
The proportion of recruits ranged from $34.3 \%$ in June 1982 to $68.5 \%$ in February 1983 (Table 2). The maximum likelihood ANOVA showed significant differences when comparing months (Proc CATMOD; $\chi^{2}=$ 863.8, $36 \mathrm{df}, \mathrm{p}<0.0001$ ). Paired chi-squared tests indicated that all differences between months were highly significant $(p<0.0001)$. When excluding the juveniles

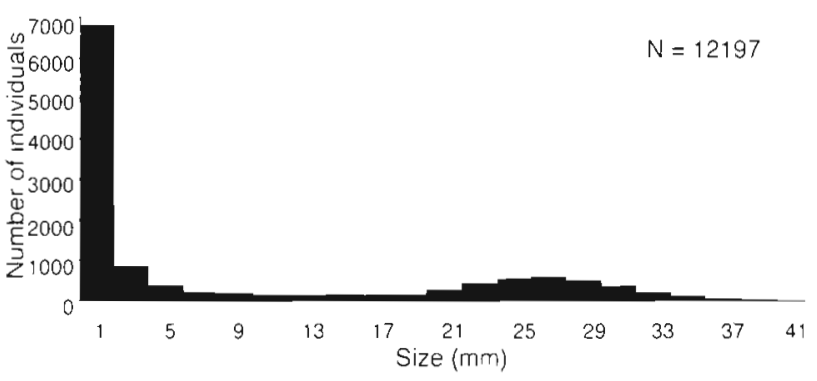

Fig. 2. Perumytilus purpuratus. Size distribution for the entire set of mussel samples taken from April 1982 to June 1983. Sampling was done on 3 platforms with different wave exposure at Las Cruces rocky intertidal 


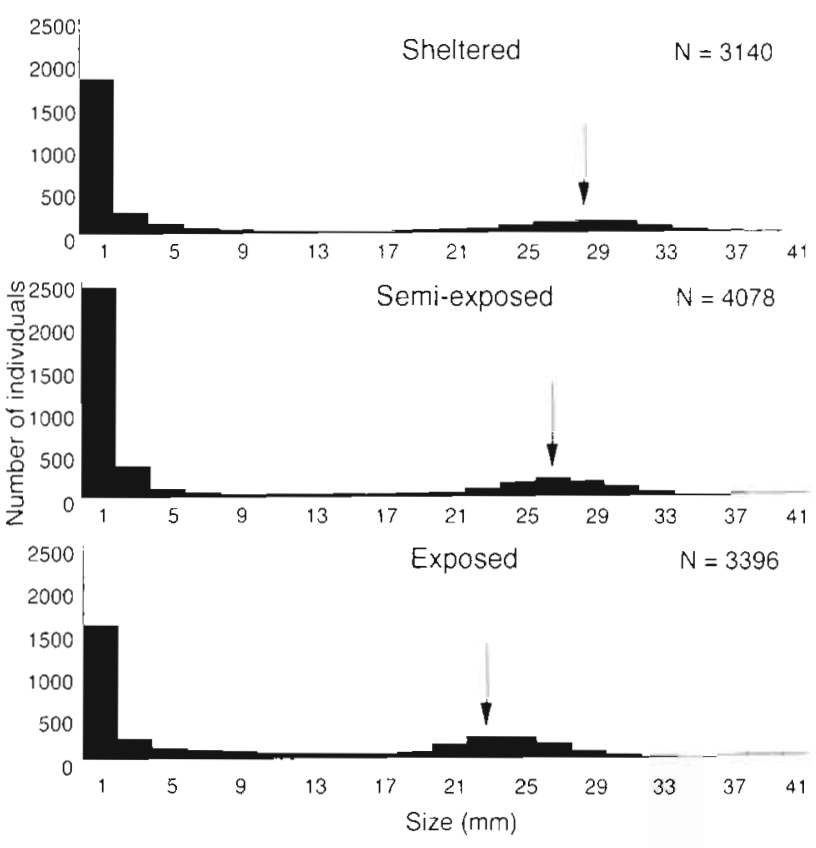

Fig. 3. Perumytilus purpuratus. Size distribution for the expused, semi-expused, and shellered platínons di Las Cruces rocky intertidal. For each platform, data was obtained pooling all months (except November 1982) and layers together Arrows ind.cate modes at adult sizes ( $>10 \mathrm{~mm}$ shell length)

Table 2. Perumytilus purpuratus. Total numbers and percentage contribution of $<2$ and $>2 \mathrm{~mm}$ mussels by month when pooling all sites together.

\begin{tabular}{|lrrrr|}
\hline \multirow{2}{*}{ Date } & \multicolumn{3}{c}{$\begin{array}{c}\text { No. of individuals } \\
<2 \mathrm{~mm}\end{array}$} & \multicolumn{2}{c|}{$\begin{array}{c}\text { Percentage (\%) } \\
<2 \mathrm{~mm}\end{array}$} & $<2 \mathrm{~mm}$ & $>2 \mathrm{~mm}$ \\
\hline Apr 1982 & 957 & 1042 & 47.87 & 55.13 \\
Jun 1982 & 400 & 765 & 34.33 & 65.67 \\
Sep 1982 & 782 & 777 & 50.16 & 49.84 \\
Nov 1982 & 1012 & 683 & 59.71 & 40.29 \\
Feb 1983 & 2025 & 933 & 68.46 & 31.54 \\
Jun 1983 & 1644 & 1177 & 58.28 & 41.72 \\
& & & & \\
\hline
\end{tabular}

Table 3. Perumytilus purpuratus. Comparisons of adult size distributions (>10 $\mathrm{mm}$ shell length) amongst months, using SMM multiple comparison (Proc GLM; SAS Institute 1988). Means with the same letter are not significantly different $(\alpha=0.01)$

\begin{tabular}{|lcccc|}
\hline Date & N & Mean & SD & $\begin{array}{c}\text { SMM multiple } \\
\text { Comparison grouping }\end{array}$ \\
\hline Apr 1982 & 706 & 24.00 & 6.12 & a \\
Jun 1982 & 616 & 24.92 & 5.85 & a \\
Sep 1982 & 573 & 23.27 & 4.73 & b \\
Feb 1983 & 620 & 24.32 & 6.84 & a \\
Jun 1983 & 609 & 24.30 & 6.40 & a \\
\hline
\end{tabular}
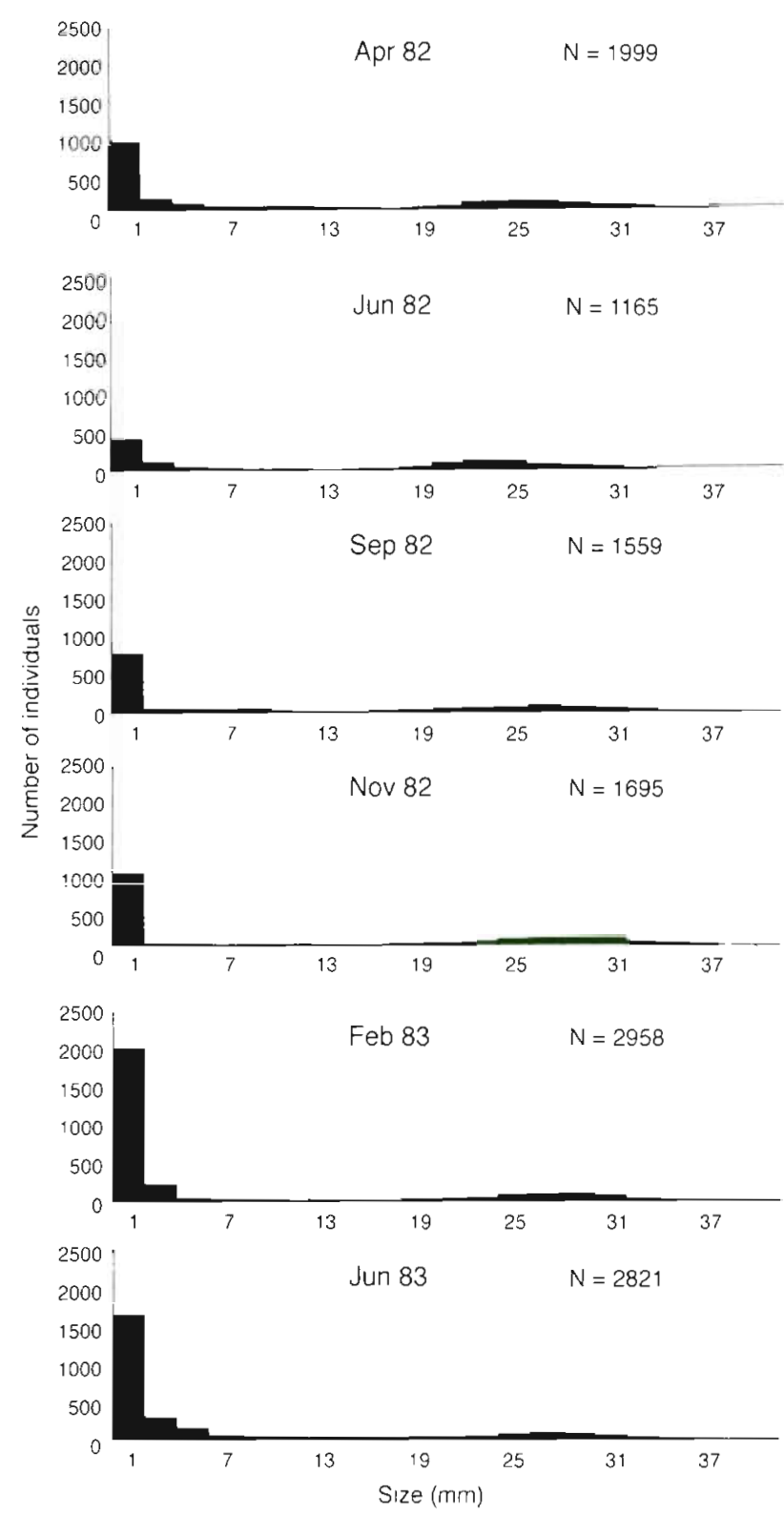

Fig. 4. Perumytilus purpuratus. Size distribution for various dates during the sampling period (April 1982 to June 1983). For each month, data was obtained pooling all platforms together

from the analysis, most mean size comparisons showed no significant differences (Table 3)

For the upper and lower layers (Fig. 5), the maximum likelihood ANOVA showed significant differences for both the whole size distribution $\left(\chi^{2}=241.4,9 \mathrm{df}, \mathrm{p}<\right.$ $0.001)$ and adult size distributions $\left(\chi^{2}=131.8,6 \mathrm{df}, \mathrm{p}<\right.$ $0.0001)$. The ANOVA on mean adult size showed significant differences when comparing the upper $(25.71 \mathrm{~mm})$ and lower $(23.16 \mathrm{~mm})$ layers $(F=126.1$, df $1, \mathrm{p}<0.0001$ ). 


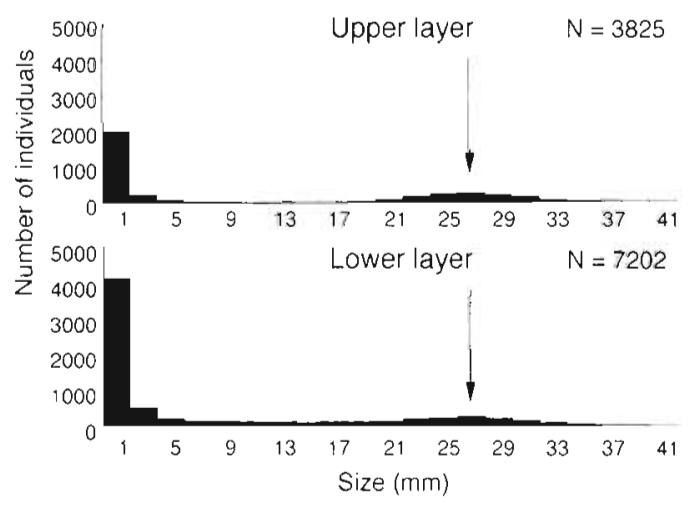

Fig. 5. Perumytilus purpuratus. Size distribution for upper and lower layers within the mussel matrices. For each layer, data was obtained pooling all platforms and months together. Arrows indicate modes at adult sizes ( $>10 \mathrm{~mm}$ shell length)

\section{DISCUSSION}

Bimodal size distributions have been reported for a wide range of organisms but the different causal mechanisms suggested probably have been misidentified until recently (Botsford et al. 1994). Most bimodal size distributions have been explained in terms of mechanisms affecting the natural mortality of individuals within a certain range of the size structure. The process of growth has scarcely been considered in most of these analyses.

Botsford et al. (1994) described a situation where bimodality can be explained by means of a size-structured model for which mortality and growth rates decrease with size. According to our findings, we suggest that bimodality in Perumytilus purpuratus rocky intertidal populations can result from similar processes.

The first mode in the size distribution of this mussel would arise due to the permanent presence of a large number of recruits in the environment (Table 2), accompanied by a high mortality rate in small individuals. Natural mortality in post-metamorphic and juvenile individuals is expected to vary during the year due to changes in environmental conditions such as temperature, humidity, and salinity. However, we suggest that other (biotic) key factors such as predation (Navarrete \& Castilla 1988) and/or intra-specific competition (Seed 1969, 1976, Guinez 1996) may help to keep natural mortality of juvenile Perumytilus purpuratus at a high rate during the whole year. Navarrete \& Castilla (1988) documented a high predation pressure on small $P$. purpuratus ( 3 to $6 \mathrm{~mm}$ shell length) by the carnivorous intertidal crabs Acanthocyclus gayi MilneEdwards et Lucas and $A$. hassleri Rathbun. Furthermore, Méndez \& Cancino (1990) and Dye (1991) reported a strong selection for small $P$. purpuratus,
$<10 \mathrm{~mm}$, by juveniles of the muricid gastropod Concholepas concholepas, another key intertidal predator on Chilean rocky shores (Castilla et al. 1979, 1994, Castilla 1981, Guisado \& Castilla 1983, Moreno et al. 1986)

The second mode, at adult sizes $(>10 \mathrm{~mm})$, could be explained as a result of differential natural mortality among size classes. We suggest that the second mode found in Perumytilus purpuratus would result from a process in which mortality decreases with increasing mussel size up to a certain limit, beyond which mortality rises due to increased exposure to wave action.

According to observations made at the Las Cruces intertidal rocky shore, wave forces vary considerably among and within platforms harboring mussel matrices. Variations were also observed over time. The wave forces experienced by the exposed platform were significantly higher than those observed on the other platforms. Wave forces experienced by the semiexposed and sheltered platforms showed significant differences in 3 out of the 6 days monitored. Intertidal wave forces at the exposed Las Cruces platform in winter were higher than those observed in summer by Palumbi (1984), using the same measuring device, at a very exposed intertidal site (Tatoosh Island, WA, USA).

Among platforms, the differences in the Perumytilus purpuratus size distributions could arise as a result of changes in the mortality rates of juvenile and adult individuals. For instance, juveniles would probably be more susceptible to changes in environmental factors such as temperature and humidity. Hence, their natural mortality could probably be higher on semiexposed and sheltered platforms (Seed 1969, Suchanek 1978). The wave force by itself would also affect survival of juveniles. Nevertheless, this effect is expected to be greatly diminished inside the mussel bed due to the wave buffering role played by the matrix itself (Suchanek 1979).

The observed differences in mean adult size could also be explained in terms of wave exposure. For instance, it can be argued that a high degree of exposure (exposed platform) can be translated into a comparative higher mortality of adult mussels due to mechanical wave removal (Castilla unpubl. results).

Natural mortality of mussels is expected to increase once they have grown to a critical size, due to increased exposure to wave action. With increasing wave force, we expect a smaller critical size for which mortality increases, thus resulting in a lower mean size for adults. Harger (1970) showed an inverse relationship between wave exposure and maximum mussel size for Mytilus edulis occurring naturally on the Santa Barbara coast.

During the period of study, the highest number of Perumytilus purpuratus mussels was always found in the 
size range between 0.5 and $0.7 \mathrm{~mm}$ shell length. Ramorino \& Campos $(1979,1983)$ reported a post-larval settling size of around $0.2 \mathrm{~mm}$ for this mussel species. Thus, the most abundant fraction of the $P$. purpuratus population can be considered as recruits. The proportion of small mussels changes throughout the year, as expected from changes in the spawners proportion reported by Lozada \& Reyes (1981). The large differences in the number of recruits observed in June 1982 and June 1983 could be due to oceanographic or climatic phenomena (e.g. El Niño-Southern Oscillation 1982-1983) that would directly affect the reproductive success of the species, and make effective recruitment a seasonal or episodic event rather than a continuous one.

Additionally, individuals of Perumytilus purpuratus smaller than $2.0 \mathrm{~mm}$ in shell length are always present in the mussel beds, in higher numbers than those observed for other mussel species such as Braquidontes granulata, Semimytilus algosus and Lassaea sp. (Castilla unpubl. data) that do not persist as adults in the $P$. purpuratus beds. This evidence suggests that a numerical threshold may exist for the number of recruits to effectively estabitish in the $P$. purpuratus beds.

The differences between the upper and lower layers of Perumytilus purpuratus could arise as a result of differential recruitment. Although the statistical analyses showed differences in the adult size distributions, the mode for both layers is the same (Fig. 5). The observed differences between layers are due to the presence of a greater number of intermediate size individuals in the lower layer rather than a higher modal value in the upper layer. The higher number of juveniles in the lower layer may be due to a higher retention of recruits. This increased retention is expected due to the following: first, the reduced turbulence (and 'washing' power) resulting from the presence of the upper layers would greatly favor the retention of recruits in the lower layers; and second, as a result of the reduced turbulence, a higher retention of suspension material and debris could facilitate settlement of recruits inside the matrix. Suchanek (1979) showed how structural complexity in mussel beds (Mytilus californianus) increases both mussel settlement and species diversity. Following the argument that wave impact is one of the determinants of the modal value for adults, a higher mode for lower layers would be expected due to reduced wave force. However, this was not observed. The modal value for lower layers could be explained as a result of decreased growth rate and maximum size, both due to reduced food supply (Coe \& Fox 1942, Seed 1969, Suchanek 1979, Kautsky 1982).

The results reported could be explained in terms of size-dependent growth and mortality rates in Perumytilus purpuratus (Alvarado unpubl.). However, the mechanisms that produce the size-dependent mortality (e.g. competition, predation, physiological stress) need to be investigated.

The method developed in this paper to collect separate mussel layers allowed us to recognize a differential pattern of recruitment between layers that otherwise would have been missed. The mechanisms that produce the higher retention of juveniles deserve further exploration in the future. So far, most of the sampling methods described to analyze mussel matrices (beds) have not given attention to the Iayer stratification phenomenon (Harger \& Landenberger 1971 Lozada \& Reyes 1981, Petersen 1984, McGrath et al 1988). This signifies a loss of information concerning mussel intra-bed dynamics.

Acknowledgements. J.C.C. acknowledges financial support given by projects DIUC 62/82 and 63/84 and FONDECYT $88 / 0432$ and 193/0684. The observations and sampling were done at the intertidal rocky shore of the Estación Costera de Investigaciones Marinas, Las Cruces. Several students collaborated during the sampling, sorting and preliminary analysis of the data. We are particularly indebted to Fernando Jara, Gladys Acosta, Ana Farias, Ernesto Ortiz and Cristián Pacheco. The paper was completed thanks to financial help given to J.L.A. through the Commission of the European Community Contract No. Cl1 -CT93-0338. Pablo Marquet, Miriam Fernández, Isabelle Minn and 2 anonymous referees suggested important changes in the original manuscnpt. We sincerely thank them

\section{LITERATURE CITED}

Botsford LW, Smith BD, Quinn JF (1994) Bimodality in size distributions: the red sea urchin Strongylocentrotus franciscanus as an example. Ecol Appl 4:42-50

Castilla JC (1981) Perspectivas de investigación en estructura y dinámica de comunidades intermareales rocosas de Chile central. II. Depredadores de alto nivel trótico. Medio Ambiente 5:190-215

Castilla JC, Branch GM, Barkai A (1994) Exploitation of two critical predators: the gastropod Concholepas concholepas and the rock lobster Jasus lalandii. In: Siegfried WR (ed) Rocky shores: exploitation in Chile and South Africa. Springer-Verlag, New York, p 101-130

Castilla JC, Durán LR (1985) Human exclusion from the rocky intertidal zone of central Chile: the effects on Concholepas concholepas (Gastropoda). Oikos 45:391-399

Castilla JC, Guisado Ch, Cancino J (1979) Aspectos ecológi$\cos$ y conductuales relacionados con la alımentación de Concholepas concholepas (Mollusca: Gastropoda: Muricidae). Biol Pesq 12:99-114

Castilla JC, Luxoro C, Navarrete SA (1989) Galleries of the crabs Acanthocyclus under intertidal mussel beds: their effects on the use of primary substratum. Rev Chil Hist Nat 62:199-204

Coe WR, Fox DL (1942) Biology of the California sea-mussel (Mytilus californianus). I. Influence of temperature, food supply, sex and age on the rate of growth. J Exp Zool 90: $1-30$

Denny MW (1987) Lift as a mechanism of patch initiation in mussel beds. J Exp Mar Biol Ecol 113:231-243 
Denny MW (1988) Biology and the mechanics of the waveswept environment. Princeton University Press, Princeton, NJ

Durán LR, Castilla JC (1989) Variation and persistence of the middle rocky intertidal community of central Chile, with and without human harvesting. Mar Biol 103:555-562

Dye AH (1991) Feed preferences of Nucella crassilabrum and juvenile Concholepas concholepas (Gastropoda: Muricidae) from a rocky shore in southern Chile. J Moll Stud 57 301-307

Griffiths CL, Seiderer JL (1980) Rock lobsters and musselslimitations and preferences in a predator prey interaction J Exp Mar Biol Ecol 44:95-109

Guiñez RE (1996) Dinámica poblacional del chorito maico, Perumytilus purpuratus (Lamarck, 1819) (Bivalvia: Mytilidae), en gradientes de exposición al oleaje. $\mathrm{PhD}$ thesis, Pontifica Universidad Católica de Chile, Facultad de Ciencias Biológicas, Santiago

Guisado Ch, Castilla JC (1983) Aspects of the ecology and growth of an intertidal juvenile population of Concholepas concholepas (Mollusca: Gastropoda: Muricidae) at Las Cruces, Chile. Mar Biol 78:99-103

Harger JRE (1970) The effect of wave impact on some aspects of the biology of sea mussels. Veliger 12:401-414

Harger JRE, Landenberger DE (1971) The effect of storms as a density dependent mortality factor on populations of sea mussels. Veliger 14:195-201

Huston MA (1986) Size bimodality in plant populations: an alternative hypothesis. Ecology 67:265-269

Huston MA, DeAngelis DL (1987) Size bimodality in monospecific populations: a critical review of potential mechanisms. Am Nat 129:678-707

Jones WE, Demetropoulos A (1968) Exposure to wave action: measurements of an important ecological parameter on rocky shores on Anglesey. J Exp Mar Biol Ecol 2:46-63

Kautsky $N$ (1982) Growth and size structure in a Baltic Mytilus edulis population. Mar Biol 68:117-133

Koehl MAR (1982) The interaction of moving water and sessile organisms. Sci Am 247:124-134

Koehl MAR (1984) How do benthic organisms withstand moving water? Am Zool 24:57-70

Koehl MAR (1986) Seaweeds in moving water: form and mechanical function. In: Givnish TH (ed) On the economy of plant form and function. Cambridge University Press Cambridge, p 603-633

Leigh EG, Paine RT, Quinn JF, Suchanek TH (1987) Wave energy and intertidal productivity. Proc Natl Acad Sci USA $84: 1314-1318$

Lozada LE (1964) Observaciones sobre la población de Perumythlus purpuratus (Lamarck) en El Tabo (1961-62) (Moll. Biv. Mytilidae). Univ Chile, Fac Filos y Ed, Santiago

Lozada LE. Reyes P (1981) Reproductive biology of a population of Perumytilus purpuratus at El Tabo, Chile (Mollusca: Bivalvia: Mytilidae). Veliger 24:147-154

McGrath D, King PA, Gosling EM (1988) Evidence for the direct settlement of Mytilus edulis larvae on adult mussel beds. Mar Ecol Prog Ser 47:103-106

Méndez MA, Cancino JM (1990) Preferencias alimentarias de ejemplares postmetamórficos y juveniles de Concholepas concholepas (Brugière 1789). Rev Biol Mar 25:109-120

Moreno CA, Lunecke KM, Lépez MI (1986) The response of an intertidal Concholepas concholepas (Gastropoda) population to protection from Man in southern Chile and the effects on benthic sessile assemblages. Oikos 46:359-364 Navarrete SA, Castilla JC (1988) Foraging activities of Chil-

This article was presented by R. N. Hughes (Senior Editorial Advisor), Bangor, United Kingdom ean intertidal crabs Acanthocyclus gayi Milne-Edwards et Lucas and A. hassleri Rathbun. J Exp Mar Biol Ecol 118 $115-136$

Navarrete SA, Castilla JC (1990) Barnacle walls as mediators of intertidal mussel recruitment: effect of patch size on the utilization of space. Mar Ecol Prog Ser 68:113-119

Oliva D, Castilla JC (1986) The effect of human exclusion on the population structure of key-hole limpets Fissurella crassa and $F$. limbata on the coast of central Chile. PSZN I Mar Ecol 7:201-217

Osorio C, Bahamonde N (1968) Moluscos bivalvos en pesquerías Chilenas. Biol Pesq 3:93

Paine RT, Castilla JC, Cancino J (1985) Perturbation and recovery patterns of starfish-dominated intertidal assemblages in Chile, New Zealand, and Washington State. Am Nat 125:679-691

Palumbi SR (1984) Measuring intertidal wave forces. J Exp Mar Biol Ecol 81:171-179

Penchaszadeh PE (1973) Ecología de la comunidad del mejillín (Braquidontes rodriguezi D'Orb) en el mediolitoral rocoso de Mar del Plata (Argentina) el proceso de recolonizacion. Physis Secc A (B Aires) 32:51-64

Petersen JH (1984) Establishment of mussel beds: attachment behavior and distribution of recently settled mussels (Mytilus californianus). Veliger 27:7-13

Pollock DE (1979) Predator-prey relationships between the rock-lobster Jasus lalandii and the mussel Aulacomya ater at Robben Island on the Cape West Coast of Africa. Mar Biol 52:347-356

Ramorino L, Campos B (1979) Desarrollo larval y postlarval de Perumytilus purpuratus (Lamarck, 1819) Bivalvia: Mytilidae. An Mus Hist Nat, Valparaíso 12:207-218

Ramorino L, Campos B (1983) Larvas y postlarvas de Mytilidae de Chile (Mollusca: Bivalvia). Rev Biol Mar 19: $143-192$

Reish DJ (1964) Studies on the Mytilus edulis community in Alamitos Bay, California: I. Development and destruction of the community. Veliger $6: 124-131$

SAS Institute Inc. (1988) SAS/STAT user's guide, Release 6.03 edn. SAS Institute Inc, Cary, NC

Seed R (1969) The ecology of Mytilus edulis L. (Lamellibranchiata) on exposed rocky shores. II. Growth and mortality. Oecologia 3:317-350

Seed R (1976) Ecology. In: Bayne BL (ed) Marine mussels: their ecology and physiology. Cambridge University Press, Cambridge, p 13-65

Suchanek TH (1978) The ecology of Mytilus edulis L. in exposed rocky intertidal communities. J Exp Mar Biol Ecol 31:105-120

Suchanek TH (1979) The Mytilus californianus community: studies on the composition, structure, organization, and dynamics of a mussel bed. PhD thesis, University of Washington, Seattle

Suchanek TH (1986) Mussels and their rôle in structuring rocky shore communities. In: Moore PG, Seed $R$ (eds) The ecology of rocky coasts. Columbia University Press, New York, p 70-96

Tegner MJ, Levin LA (1983) Spiny lobsters and sea-urchins: an analysis of a predator-prey interaction. J Exp Mar Biol Ecol 73:125-150

Tokeshi M, Romero L, Tarazona J (1989) Spatial coexistence of mussel associated free-ranging polychaetes in a subtropical intertidal habitat. J Anim Ecol 58:681-692

Vogel S (1984) Drag and flexibility in sessile organisms. Am Zool 24:37-44

Manuscript first received: September 25, 1994

Revised version accepted: October 20, 1995 